\title{
New Gerbera Daisy Varieties for Large Containers and Flower Gardens ${ }^{1}$
}

\section{Zhanao Deng ${ }^{2}$}

\section{Executive Summary}

'Funtastic ${ }^{\text {Tm }}$ Tangerine Eye' and 'Funtastic ${ }^{\text {Tm }}$ Golden Eye' have been selected and tested specifically for use in large containers. These cultivars produce large, powdery mildewresistant plants and large, attractive flowers in orange-red or yellow-orange that complement the existing Funtastic ${ }^{\text {Tw }}$ series of gerbera cultivars.

Gerbera daisy is one of the most popular flowers in the United States (Behnke, 1984; Rogers and Tjia, 1990). Recently, interest has increased in growing gerberas in large containers (8 inches or larger) for indoor or outdoor use. Because there has been a shortage of cultivars suitable for such containers (Channel, 2005), greenhouse growers and nurseries often rely on two strategies to produce gerberas in large containers. One method uses cut flower cultivars and growth retardants to shorten the flower peduncles; however, finished plants often have few flowers and peduncles are still too tall for the pot size. Other growers have tried to use small cultivars, but finished gerbera plants tend to be too small and do not satisfactorily fill up the containers.

Previously, we released six gerbera cultivars for use in large containers (Deng and Harbaugh, 2010). These cultivars are being marketed under the Funtastic ${ }^{\mathrm{Tx}}$ series and have shown exceptional heat tolerance in industry and/or university trials (Siktberg, 2012). Some of these cultivars were selected as "Best of the Best" in the University of Georgia garden trials (Trial Gardens, 2012) (http://ugatrial. hort.uga.edu/index.cfm) and as top performers in the Ohio State University garden trials (OSU, 2011). The current series consists of five flower colors (white, light pink, yellow, orange, and orange-red). Additional cultivars were needed to expand the plant palette in this series.

'Funtastic ${ }^{\text {Tx }}$ Tangerine Eye' and 'Funtastic ${ }^{\text {Tx }}$ Golden Eye' were selected and tested specifically for the large-container flower market. These cultivars produce large plants, with large attractive flowers and appropriate peduncle heights for use in larger containers. These gerberas also express moderate to high levels of resistance to powdery mildew, the most common and important disease in gerbera production and gardening (Chase, 2001; Moyer and Peres, 2008).

\section{Description}

Descriptions of color for plant parts are based on comparison with the Royal Horticultural Society Colour Chart (Royal Horticultural Society, 1986). Plants used for describing color were 3 months old, started from tissue culture liners, and grown in 8-inch containers in a greenhouse covered with a $30 \%$ shading cloth. Plant growth regulators were not applied to the plants.

Mature plants of 'Funtastic ${ }^{\text {Tw }}$ Tangerine Eye' were about 20 inches tall and 24 inches wide (Table 1, Figure 1). Leaves were simple and pinnately lobed, with deep lobes in the basal third and shallow lobes from the central third up to the top third. The upper and lower leaf surfaces were

1. This document is ENH1221, one of a series of the Environmental Horticulture Department, UF/IFAS Extension. Original publication date September 2013. Visit the EDIS website at http://edis.ifas.ufl.edu.

\section{Zhanao Deng, associate professor, Gulf Coast Research and Education Center, Wimauma FL.}

The Institute of Food and Agricultural Sciences (IFAS) is an Equal Opportunity Institution authorized to provide research, educational information and other services only to individuals and institutions that function with non-discrimination with respect to race, creed, color, religion, age, disability, sex, sexual orientation, marital status, national origin, political opinions or affiliations. U.S. Department of Agriculture, Cooperative Extension Service, University of Florida, IFAS, Florida A\&M University Cooperative Extension Program, and Boards of County Commissioners Cooperating. Nick T. Place, Dean. 
medium-green. Flowers (Table 1, Figure 2) were of the single type and had a diameter of 4.1 to 5.4 inches. The upper and lower sides of the outer ray florets were orangered and yellow-orange, respectively. Disc florets were orange-red. Peduncles were 14.2 to 17.7 inches long.

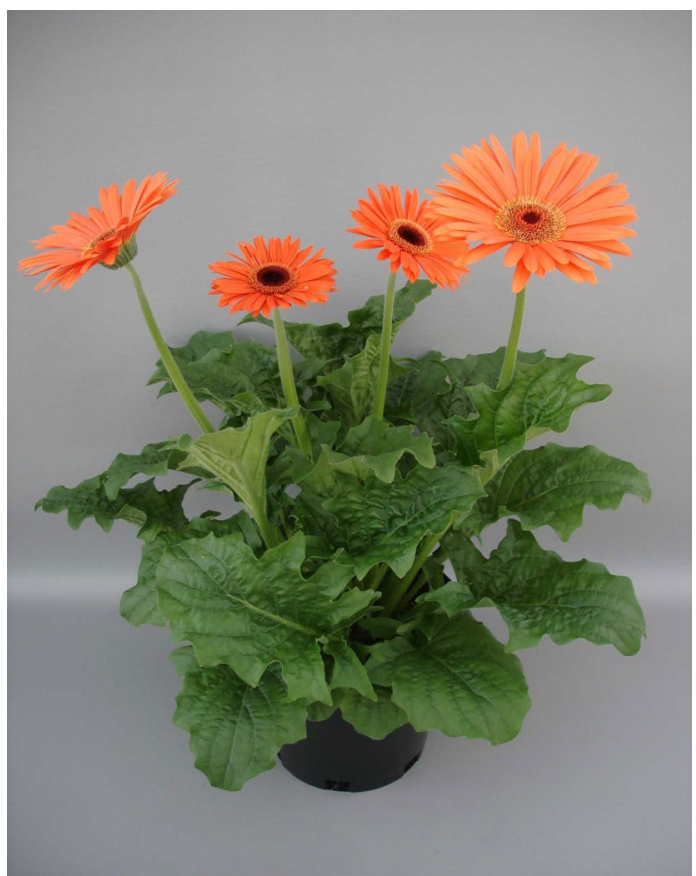

Figure 1. A single plant (about 10 weeks old) of ${ }^{\prime}$ Funtastic $^{\mathrm{TM}}$ Tangerine Eye' grown from a single tissue culture liner in an 8-inch container. Credits: Gail T. Bowman (UF/IFAS/GCREC)

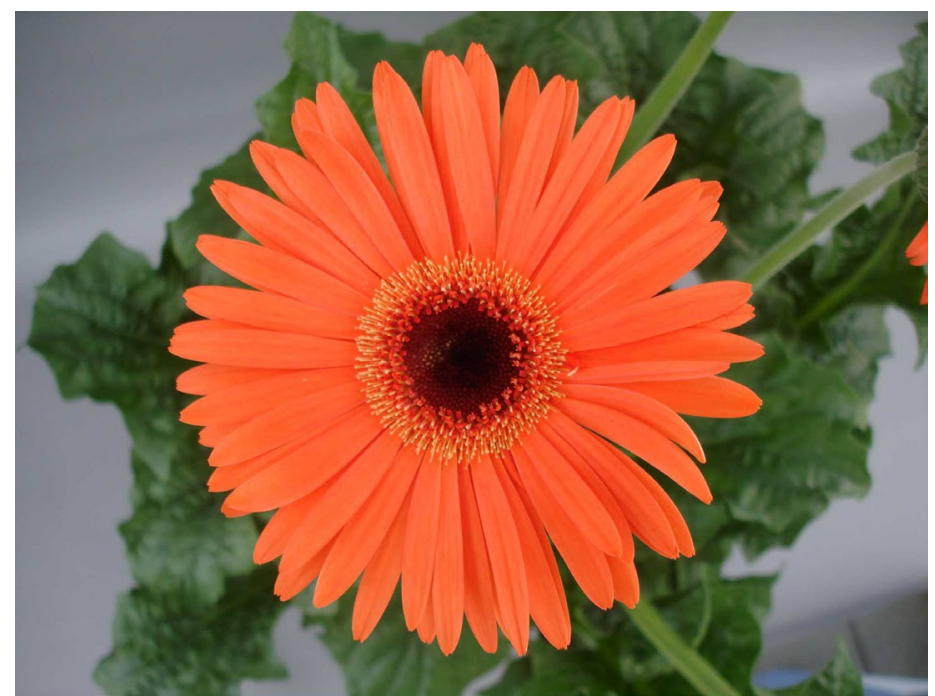

Figure 2. Flower of 'Funtastic ${ }^{\mathrm{TM}}$ Tangerine Eye'.

Credits: Gail T. Bowman (UF/IFAS/GCREC)

Mature plants of 'Funtastic ${ }^{\text {'m }}$ Golden Eye' were about 21 inches tall and 26 inches wide (Table 1, Figure 3). Leaves were simple and pinnately lobed, with deep lobes in the basal third, shallow lobes in the central third, and no obvious lobes near the top third. The upper leaf surface was medium-green. Flowers (Table 1, Figure 4) were of the single type and 4.1 to 4.7 inches in diameter. The upper side of the outer ray florets was bi-colored, yellow near the base and transitioning to orange toward the apex. The lower surface was yellow. Disc florets were orange. Peduncles of mature flowers were 16.9 to 20.5 inches long.

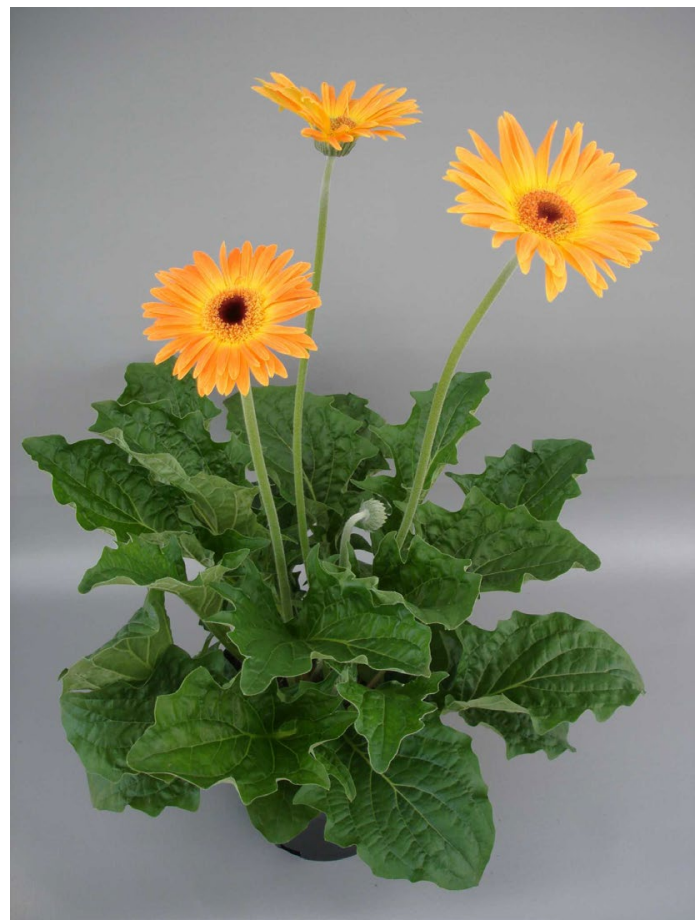

Figure 3. 'Funtastic ${ }^{\mathrm{TM}}$ Golden Eye' plant (about 10 weeks old) grown from a single tissue culture liner in an 8-inch container. Credits: Gail T. Bowman (UF/IFAS/GCREC)

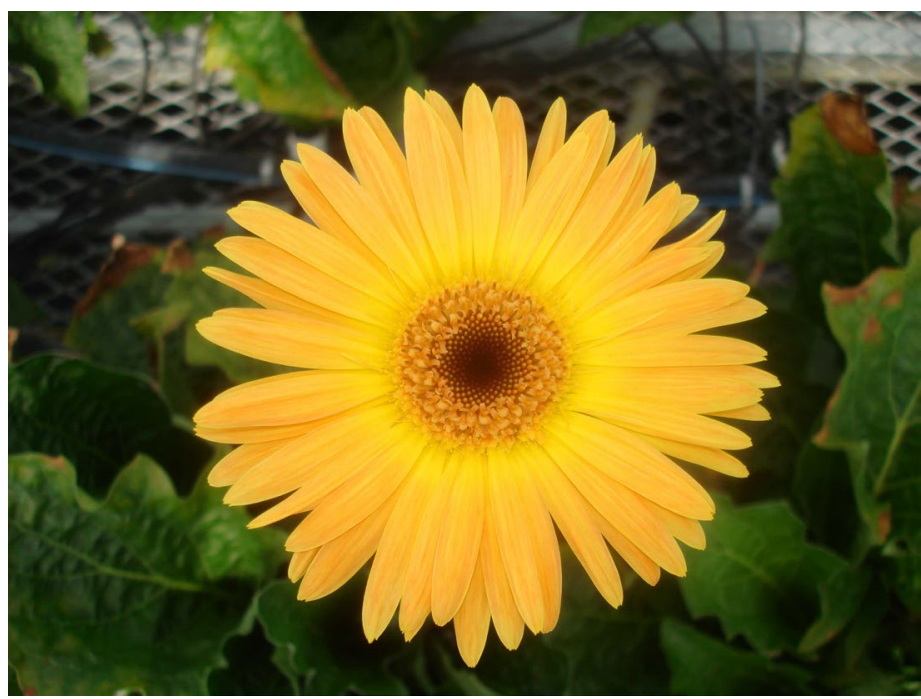

Figure 4. Flower of 'Funtastic ${ }^{\mathrm{TM}}$ Golden Eye'. Credits: Gail T. Bowman (UF/IFAS/GCREC) 


\section{Horticultural characteristics}

Three experiments (Expt. 1 to 3) were conducted in the greenhouse to evaluate horticultural characteristics, including plant quality, days to flower, flower size, flower quality, peduncle length, and flower count. In Expt. 1 (December 2008 to March 2009), tissue culture liners (Agri-Starts, Apopka, FL) were transplanted on December 9, 2008 into 8 inch-diameter containers filled with the commercial potting mix Fafard 3B (Conrad Fafard) amended with the controlled release fertilizer Osmocote (15N-3.9P-10K, 5 to 6 months) at 0.33 pounds per cubic feet and the trace element fertilizer MicroMax at 0.07 pounds per cubic feet. Potted plants were grown on metal benches with $\sim 20$ inch spacing between pots in a greenhouse in Wimauma, FL. Irrigation was through drip tubes. Temperatures inside the greenhouse ranged from $64^{\circ} \mathrm{F}$ (night) to $92^{\circ} \mathrm{F}$ (day). Two additional hours of incandescent photoperiodic lighting were provided between December 9, 2008 and March 17, 2009. Fungicides and insecticides were applied as needed to control powdery mildew (Moyer and Peres, 2012) and western flower thrips (Price and Nagle, 2012). The number of flowers produced per potted plant was recorded weekly from January 30, 2009 through March 17, 2009. The number of days from transplanting to the opening of the third flower was recorded as the production time needed to produce marketable potted flowering plants. Flower quality was rated on a 1-to- 5 scale: $1=$ very poor; $3=$ fair, some blemishes, but acceptable; and $5=$ excellent, bright, uniform, and no blemishes. Plant quality was rated on February 17, 2009, using a 1-to-5 scale: $1=$ few leaves or long petioles, container surface visible, very poor and unacceptable as flowering potted plants; 3 = fair and meeting the minimum standard for marketability; and $5=$ excellent, full, symmetrical, attractive flowering plants.

Expt. 2 was conducted in August through November 2009. Gerbera tissue culture liners were transplanted on August 13, 2009 into 8-inch plastic containers filled with the Fafard 3B potting mix (Conrad Fafard) amended as in Expt. 1. Potted plants were grown as described in Expt. 1. The greenhouse was covered with aluminum shading cloth (Aluminet ${ }^{\oplus}$, Signature Supplies, Inc., Lakeland, FL) with $\sim 30 \%$ light exclusion. Temperatures in the greenhouse were between $70{ }^{\circ} \mathrm{F}$ (night) and $95^{\circ} \mathrm{F}$ (day). Additional photoperiodic lighting (incandescent bulbs, 2 hours) began on September 15, 2009 through the end of the experiment. The number of new flowers produced per plant was recorded weekly from September 25, 2009 through November 20, 2009. Flower and plant quality were rated as in Expt. 1.
Expt. 3 was conducted in April through July 2012. Tissue culture liners (Agri-Starts) were transplanted on April 4, 2012 into 8-inch diameter plastic containers filled with amended Fafard 3B potting mix. Growing conditions were similar to those described for Expt. 2. The number of flowers produced per potted plant was recorded weekly from June 12, 2012 through July 31, 2012. Flower and plant quality were rated as in Expt. 1.

Two types of commercial cultivars were included for comparison. The first were cut flower cultivars that were used to produce gerberas in large containers, including 'Bimini' and 'Pensacola.' 'Funtastic ${ }^{\text {Tx }}$ Fire Orange' or 'Funtastic ${ }^{\text {Tm }}$ Canary' were also used as checks since these cultivars were developed and recently released for use in large containers (Deng and Harbaugh, 2010). The experimental design was a randomized complete block design with five (Expt. 1), eight (Expt. 2), or six (Expt. 3) replicates. The experimental unit was a single containerized plant grown from one tissue culture liner.

'Funtastic ${ }^{\text {th }}$ Tangerine Eye': Plants of this cultivar opened third flowers about 82 days after transplanting in December 2008 (Expt. 1) or April 2012 (Expt. 3) and about 61 days after transplanting in August 2012 (Expt. 2) (Table 2). The time to third open flower was about 13 days shorter for 'Funtastic ${ }^{\text {Tx }}$ Tangerine Eye' than for 'Bimini' in Expt. 1 and appeared to be 4 days shorter (not significantly different) in Expt. 2. The time to third open flower was about 19 days shorter for 'Funtastic ${ }^{\text {тx }}$ Tangerine Eye' than for 'Pensacola' in Expt. 2. However, the time to third open flower was about 8 days longer for 'Funtastic ${ }^{\text {Th }}$ Tangerine Eye' than for 'Funtastic ${ }^{\text {Th }}$ Fire Orange.' The time to third open flower was also about 12 days longer for 'Funtastic ${ }^{\text {Tx }}$ Tangerine Eye' than for 'Funtastic ${ }^{\text {Th }}$ Canary' in Expt. 1 and appeared to be 4 days longer in Expt. 2 and 3.

Peduncles of 'Funtastic ${ }^{\text {'x }}$ Tangerine Eye' were 14.2 to 17.2 inches, similar to the peduncle length of 'Funtastic ${ }^{\text {тx }}$ Canary', but approximately 7 to 9 inches shorter than that of 'Bimini' or 'Pensacola', and 2 to 3 inches shorter than that of 'Funtastic ${ }^{\text {tm }}$ Fire Orange' (Table 2). Flowers of 'Funtastic ${ }^{\text {tm }}$ Tangerine Eye' were 4.4 to 5.4 inches, similar to the flower size of 'Funtastic ${ }^{\text {tix }}$ Fire Orange', a large-flowered cultivar (Table 2). Flower quality rating of 'Funtastic ${ }^{\text {'m }}$ Tangerine Eye' was 3.9 to 4.1, similar to that of 'Funtastic ${ }^{\text {Tix }}$ Fire Orange' in Expt. 1 and 2 and similar to that of 'Funtastic Canary' in Expt. 3, but lower than that of 'Funtastic ${ }^{\text {Tm }}$ Canary' in Expt. 1 and 2 (Table 2). Plants of 'Funtastic ${ }^{\mathrm{Tm}}$ Tangerine Eye' received similar quality ratings with 'Bimini' in Expt. 1 and similar ratings with 'Bimini,' 'Pensacola', 'Funtastic ${ }^{\mathrm{Tm}}$ Fire Orange', and 'Funtastic ${ }^{\mathrm{TN}}$ Canary' in Expt. 
2 (Table 2). Plant quality rating for ' ${ }^{\text {Funtastic }}{ }^{\text {Ti }}$ Tangerine Eye' (3.0 in Expt. 1 and 2.9 in Expt. 3) was lower than the rating for 'Funtastic ${ }^{\text {Th }}$ Fire Orange' in Expt. 1 (3.8) and the rating for 'Funtastic ${ }^{\text {Tm }}$ Canary' in Expt. 1 and 3 (3.8 and 3.8, respectively). The lower plant quality ratings for 'Funtastic ${ }^{\text {'m }}$ Tangerine Eye' in Expt. 1 and 3 were due to fewer numbers of leaves on some plants.

'Funtastic ${ }^{\text {Tx }}$ Tangerine Eye' produced similar numbers of flowers (4.2) compared with 'Bimini' (3.0) in Expt. 1, but $66 \%$ more flowers than 'Bimini' and $172 \%$ more flowers than 'Pensacola' in Expt. 2 (Table 3). Compared to 'Funtastic ${ }^{\mathrm{Tx}}$ Fire Orange, 'Funtastic ${ }^{\mathrm{Tx}}$ Tangerine Eye' was less productive, with $25 \%$ to $32 \%$ lower flower counts in Expt. 1 and 2. 'Funtastic ${ }^{\text {Ts }}$ Tangerine Eye' produced 25\% fewer flowers than 'Funtastic ${ }^{\text {tw }}$ Canary' (4.2 vs. 6.2) in Expt. 1, but it was comparable to 'Funtastic ${ }^{\text {tu }}$ Canary' in flower production (6.8 vs. 7.6 and 8.0 vs. 10) in Expt. 2 and 3.

'Funtastic ${ }^{\text {Tm }}$ Golden Eye': Plants of this cultivar opened third flowers in 91.6 days after transplanting in December 2008 (Expt. 1) and 74.3 days after transplanting in August 2009 or April 2012 (Expt. 2 or 3) (Table 2). Time to third open flower for 'Funtastic ${ }^{\text {Tx }}$ Golden Eye' was similar to the time to third open flower for 'Bimini' or 'Pensacola', but it was 18 to 23 days longer than the time to third open flower for 'Funtastic ${ }^{\text {Th }}$ Fire Orange' or 'Funtastic ${ }^{\text {Th }}$ Canary' in Expt. 1 and 2.

Peduncles of 'Funtastic ${ }^{\text {Tn }}$ Golden Eye' were 16.9 to 20.5 inches tall, 4 to 6 inches shorter than the peduncle length of 'Bimini' (23.0 to 24.2 inches) or 'Pensacola' ( 24.6 inches), but similar to the peduncle length of 'Funtastic ${ }^{\text {tix }}$ Fire Orange' (16.4 to 20.4 inches) (Table 2). Flowers of 'Funtastic $^{\text {Tx }}$ Golden Eye' were large, about 4.1 to 4.7 inches. This size is similar to the flower size of 'Funtastic ${ }^{\text {Tw }}$ Canary' (3.9 to 4.3 inches) in Expt. 1 and 2 but about $3 / 4$ inches larger than the flower size of 'Funtastic ${ }^{\text {Tw }}$ Canary' (3.6 inches) in Expt. 3 (Table 2). Flowers of 'Funtastic ${ }^{\text {tw }}$ Golden Eye' were very attractive and received a quality rating of 3.9 to 4.3 in three experiments, which was similar to the flower quality rating of 'Funtastic ${ }^{\text {Tu }}$ Canary'(3.8) in Expt. 1, lower than that of 'Funtastic $^{\text {'m }}$ Canary' (4.8) in Expt. 2, but higher than that of 'Funtastic ${ }^{\text {tx }}$ Canary' (3.8) in Expt. 3 (Table 2). Flower quality rating of 'Funtastic ${ }^{\text {th }}$ Golden Eye' was similar to that of 'Funtastic $^{\text {Tx }}$ Fire Orange' (3.8 to 4.1) in both Expt. 1 and 2. Plant quality rating was 3.8 to 4.9 for 'Funtastic ${ }^{\text {Tx }}$ Golden Eye', higher than the plant quality rating for 'Bimini' (3.4 to 4.1) or 'Pensacola' (4.3), and comparable to, or even higher than, the quality rating for 'Funtastic ${ }^{\text {ts }}$ Fire Orange' (3.8 to 4.1) and 'Funtastic ${ }^{\text {tm }}$ Canary' (3.8 to 4.8). Plant quality rating was generally higher for 'Funtastic ${ }^{\text {Tw }}$ Golden Eye' (3.8 to 4.9) than for 'Funtastic ${ }^{\text {tix }}$ Tangerine Eye' (2.9 to 4.5) (Table 3).

'Funtastic ${ }^{\text {Tx }}$ Golden Eye' produced similar numbers of flowers (3.6 to 3.4) with 'Bimini' (3.9 to 4.1) or 'Pensacola' (2.5) in Expt. 1 and 2 (Table 3). Although 'Funtastic ${ }^{\text {Tx }}$ Golden Eye' was similarly productive as 'Funtastic ${ }^{\mathrm{Tm}}$ Canary' in one experiment (Expt. 3), 'Funtastic ${ }^{\text {Tx }}$ Golden Eye' was significantly less productive than 'Funtastic ${ }^{\text {rm }}$ Fire Orange' (5.6 to 10.0) and Funtastic ${ }^{\text {th }}$ Canary' (6.2 to 7.6 ) in two experiments (Expt. 1 and 2).

\section{Powdery mildew susceptibility}

Five experiments were conducted to assess the resistance (or susceptibility) level of 'Funtastic ${ }^{\text {Ts }}$ Tangerine Eye' and 'Funtastic ${ }^{\text {Tw }}$ Golden Eye' to powdery mildew. Expt. 4, 6 and 7 were done in parallel with Expt. 1 to 3. Gerbera tissue culture liners, the potting mix, irrigation, and fertilization were the same as Expt. 1 to 3, but the potted plants were grown under a plastic tunnel within a screen house with $\sim 50 \%$ light exclusion rather than in the greenhouse. No temperature control or additional photoperiodic lighting was provided in the screen house. Plants were subjected to natural powdery mildew disease pressures, and fungicides were not applied throughout the experiments. In Expt. 4, powdery mildew severity on gerbera plants was assessed at week 6 (January 21, 2009), 8 (February 4, 2009), 10 (February 18, 2009), 12 (March 4, 2009), and 14 (March 18, 2009) after transplanting, using a scale of 1 to 10 as described by Hausbeck et al. (2002). In Expt. 6, powdery mildew severity was assessed at week 6 (October 1, 2009), 8 (October 15, 2009), and 10 (October 29, 2009) after transplanting. In Expt. 7, powdery mildew severity was assessed at week 6 (May 25, 2012), 8 (June 29, 2012), 10 (July 20, 2012), and 12 (August 3, 2012) after transplanting. In addition, newly opened flowers were recorded weekly over a period of 6 to 9 weeks for plants under natural powdery mildew disease pressures.

Expt. 5 and 8 were conducted using mature, flowering gerbera plants that were grown as described in Expt. 1 and 3. These plants were grown in the greenhouse and subjected to natural powdery mildew disease pressures in the greenhouse. In Expt. 5, powdery mildew severity was evaluated on April 24, May 8, May 22, and June 11, 2009, and in Expt. 8, powdery mildew severity was evaluated on August 3, 2012.

A randomized complete block design was used in these experiments, with five (Expt. 4), five (Expt. 5), six (Expt. 6), four (Expt. 7), or six (Expt. 8) replications. The 
experimental unit was a single containerized plant. Similarly, 'Funtastic ${ }^{\text {Tix }}$ Fire Orange, 'Funtastic ${ }^{\text {Tw }}$ Canary', 'Bimini', and/or 'Pensacola' were included as check cultivars.

In Expt. 4, powdery mildew symptoms first appeared on 'Bimini' plants 8 weeks after transplanting, and the average severity rating of all entries increased rapidly in the following six weeks: from 1.7 on February 18, 2009 to 4.3 on March 4, and then to 6.5 on March 18, 2009. Similarly severe powdery mildew was observed in Expt. 5 between April and June 2009. The overall average powdery mildew severity rating of all plants in the experiment was between 4.9 and 5.8. Plants of 'Bimini' and 'Pensacola' were highly susceptible to powdery mildew. Powdery mildew was much less severe in Expt. 6, 7, and 8.

Plants of 'Funtastic ${ }^{\text {tw }}$ Tangerine Eye' received the lowest powdery mildew severity ratings in all five experiments, and its rating was below 3.0 in four experiments (Table 4). These results indicate a high level of powdery mildew resistance in this cultivar. Under natural powdery mildew pressures, 'Funtastic ${ }^{\text {TM }}$ Tangerine Eye' produced similar numbers of flowers with 'Funtastic ${ }^{\text {Tx }}$ Fire Orange' in Expt. 4 and 5, but fewer flowers in Expt. 6 (Table 5). 'Funtastic ${ }^{\mathrm{TM}}$ Tangerine Eye' produced similar numbers of flowers with 'Funtastic ${ }^{\text {ru }}$ Canary' in two experiments (Expt. 5 and 7) and fewer flowers in other two experiments (Expt. 4 and 6).

The powdery mildew severity ratings of 'Funtastic ${ }^{\text {Th }}$ Golden Eye' were similar to those of 'Funtastic ${ }^{\text {Ti }}$ Fire Orange' in all three experiments (Table 4). 'Funtastic ${ }^{\text {ti }}$ Golden Eye' had less powdery mildew than 'Funtastic ${ }^{\text {Tw }}$ Canary' in Expt. 4 and Expt. 5 when disease pressure was high, but similar powdery mildew severity ratings in Expt. 6, 7 and 8 when disease pressure was relatively low. These results indicate a moderate level of powdery mildew resistance in 'Funtastic ${ }^{\mathrm{Tn}}$ Golden Eye'. Again plants of 'Funtastic ${ }^{\mathrm{mm}}$ Golden Eye' produced fewer flowers than 'Funtastic ${ }^{\text {tix }}$ Fire Orange' and 'Funtastic ${ }^{\text {Th }}$ Canary' in the majority or all of the experiments (Table 5).

\section{Summary}

'Funtastic ${ }^{\text {Th }}$ Tangerine Eye' and 'Funtastic ${ }^{\text {Tm }}$ Golden Eye' produced attractive flowers and high quality plants with peduncle and plant heights appropriate for use in large containers. These new cultivars had many similar plant and flower characteristics compared to the existing Funtastic ${ }^{\text {rm }}$ series bred and released for use in large containers. They have shown a moderate to high level of resistance to powdery mildew, a trait expected to be highly beneficial to greenhouse and nursery growers in reducing pesticide use and costs and for producing highly marketable finished potted gerbera. The powdery mildew resistance in these cultivars will likely be very beneficial to consumers in preventing significant damage from powdery mildew.

Plants of 'Funtastic ${ }^{\text {Tx }}$ Tangerine Eye' and 'Funtastic ${ }^{\text {Tx }}$ Golden Eye' tend to be slower than 'Funtastic $c^{\text {Th }}$ Fire Orange' or 'Funtastic ${ }^{\text {Tu }}$ Canary' in leaf and flower development for the first two to three weeks after transplanting, resulting in fewer leaves and/or fewer flowers on finished potted plants. This crop-timing issue can be overcome by planting two tissue culture liners per container, or planting one plug two weeks earlier than other Funtastic ${ }^{\mathrm{TT}}$ cultivars, so that production time would be similar to other cultivars in the Funtastic $^{\text {Ti }}$ series.

\section{Availability}

The Florida Agricultural Experiment Station has applied for plant patents for 'Funtastic ${ }^{\text {Tm }}$ Tangerine Eye' and 'Funtastic ${ }^{\mathrm{Ts}}$ Golden Eye. Production of these cultivars is to be with a licensing agreement with the Florida Foundation Seed Producers, Inc., P.O. Box 309, Greenwood, FL 32443. Information on propagation and/or production agreements can be obtained from the Florida Foundation Seed Producers, Inc. (http://ffsp.net/).

\section{Greenhouse Production and Plant Care in Large Containers or Flower Gardens}

These cultivars are vegetatively propagated through tissue culture. Information on the sources of tissue culture liners for these cultivars can be obtained from the Florida Foundation Seed Producers, Inc. For information on greenhouse production of these and other gerberas, refer to Dole and Wilkins (1999), Kessler (1999), and Rogers and Tjia (1990). For information about planting and caring for gerberas in the landscape, refer to Park-Brown et al. (2011). 


\section{References}

Behnke, M. 1984. Gerbera production. Grower Talks 47:94-97.

Channel, C. 2005. Gerbera trials rate plants. GM Pro 25:30-31.

Chase, A.R. 2001. 2001 Update on powdery mildew control. GPN - Greenhouse Product News 11(7): 44-46.

Deng, Z. and B.K. Harbaugh. 2010. UFGE 4141, UFGE 7014, UFGE 7015, UFGE 7023, UFGE 7032, and UFGE 7034: Six new gerbera cultivars for marketing flowering plants in large containers. HortScience 45(6):971-974.

Dole, J.M. and H.F. Wilkins. 1999. Gerbera. In: Dole and Wilkins (ed.) Floriculture, principles and species. Prentice Hall, Upper Saddle River, NJ.

Hausbeck, M.K., W.R. Quackenbush, and S.D. Linderman. 2002. Evaluation of cultivars of African daisy for resistance to powdery mildew, 2002. B\&C Tests 18:O0004.

Kessler, J. K., Jr. 1999. Greenhouse production of gerbera daisies. ANR-1144. Auburn: Alabama Cooperative Extension System. http://www.aces.edu/pubs/docs/A/ANR-1144

Moyer, C. and N.A. Peres. 2012. Powdery mildew of gerbera daisy. Gainesville: University of Florida Institute of Food and Agricultural Science. http://edis.ifas.ufl.edu/pp257
OSU trials reveal top-performing annuals. GPN Greenhouse Product News. 3 Nov. 2012. http://www.gpnmag.com/ osu-trial-results-reveal-top-performing-annuals.

Park-Brown, S., B. Tjia, R.J. Black, and Z. Deng. 2011. Gerberas at a glance. Cir 527. Gainesville: University of Florida Institute of Food and Agricultural Sciences. http:// edis.ifas.ufl.edu/mg034

Price, J.F. and C. Nagle. 2012. Pesticide options for important insect, mite, and mollusk pests of commercial flowers in Florida. Gainesville: University of Florida Institute of Food and Agricultural Science. http://edis.ifas.ufl.edu/ig162

Rogers, M.N. and B.O. Tjia. 1990. Gerbera production for cut flowers and pot plants. Timber Press, Portland, Ore.

Royal Horticultural Society. 1986. Royal Horticultural Society colour chart. Royal Hort. Soc., London.

Siktberg, R. 2012. The newest trends for blooming potted plants. Greenhouse Grower. 26 Jan. 2012. http://www.greenhousegrower.com/article/24710/ the-newest-trends-for-blooming-potted-plants.

The Trial Gardens at UGA. 2012. Best of the Best. http:// ugatrial.hort.uga.edu/.

Table 1. Summary of major plant and flower characteristics of 'Funtastic ${ }^{\mathrm{TM}}$ Tangerine Eye' and 'Funtastic $^{\mathrm{TM}}$ Golden Eye' based on Expt. 1 to 3

\begin{tabular}{|c|c|c|}
\hline Characteristic & Funtastic $^{\mathrm{TM}}$ Tangerine Eye & Funtastic $^{\mathrm{TM}}$ Golden Eye \\
\hline Plant size (height $\times$ width) (in) & $20 \times 24$ & $21 \times 26$ \\
\hline Flower form & Single & Single \\
\hline Flower color (ray florets) & Orange-red & Bicolored, yellow, and orange \\
\hline Eye color (disc florets) & Orange-red & Orange \\
\hline Flower size (diameter, in) & 4.1 to 5.4 & 4.1 to 4.7 \\
\hline Peduncle height (in) & 14.2 to 17.7 & 16.9 to 20.5 \\
\hline
\end{tabular}


Table 2. Horticultural characteristics of 'Funtastic ${ }^{\mathrm{TM}}$ Tangerine Eye' and 'Funtastic ${ }^{\mathrm{TM}}$ Golden Eye' in comparison to 'Bimini', 'Pensacola',

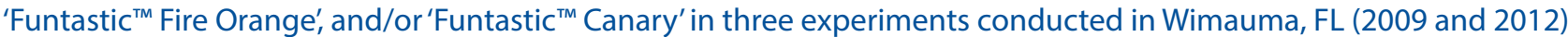

\begin{tabular}{|c|c|c|c|c|c|}
\hline Cultivars & $\begin{array}{l}\text { Days to 3rd open } \\
\text { flowers (no.) }\end{array}$ & Peduncle height (in) & Flower size (in) & Flower quality & Plant quality ${ }^{2}$ \\
\hline & \multicolumn{5}{|c|}{ Expt. 1 (Dec. 2008 to Mar. 2009) } \\
\hline $\begin{array}{c}\text { Funtastic }^{T M} \text { Tangerine } \\
\text { Eye }\end{array}$ & 82.0 & 14.2 & 5.4 & 3.9 & 3.0 \\
\hline $\begin{array}{c}\text { Funtastic }{ }^{T M} \text { Golden } \\
\text { Eye }\end{array}$ & 91.6 & 17.0 & 4.7 & 4.2 & 4.2 \\
\hline Bimini & 95.0 & 23.0 & 4.4 & 5.0 & 3.4 \\
\hline $\begin{array}{l}\text { Funtastic }^{\mathrm{TM}} \text { Fire } \\
\text { Orange }\end{array}$ & 74.2 & 16.4 & 5.1 & 3.8 & 3.8 \\
\hline \multirow[t]{2}{*}{ Funtastic ${ }^{T M}$ Canary } & 69.6 & 15.2 & 4.3 & 4.8 & 3.8 \\
\hline & \multicolumn{5}{|c|}{ Expt. 2 (Aug. to Nov. 2009) } \\
\hline $\begin{array}{c}\text { Funtastic }^{T M} \text { Tangerine } \\
\text { Eye }\end{array}$ & 60.5 & 17.2 & 4.4 & 3.9 & 4.5 \\
\hline $\begin{array}{c}\text { Funtastic }^{\mathrm{TM}} \text { Golden } \\
\text { Eye }\end{array}$ & 74.3 & 20.5 & 4.4 & 3.9 & 4.9 \\
\hline Bimini & 64.5 & 24.2 & 4.2 & 4.8 & 4.1 \\
\hline Pensacola & 79.5 & 24.6 & 4.4 & 4.3 & 4.3 \\
\hline $\begin{array}{l}\text { Funtastic }{ }^{\mathrm{TM}} \text { Fire } \\
\text { Orange }\end{array}$ & 52.9 & 20.4 & 4.6 & 4.2 & 4.1 \\
\hline \multirow[t]{2}{*}{ Funtastic ${ }^{\mathrm{TM}}$ Canary } & 56.0 & 14.9 & 3.9 & 4.8 & 4.8 \\
\hline & \multicolumn{5}{|c|}{ Expt. 3 (Apr. to July 2012) } \\
\hline $\begin{array}{c}\text { Funtastic }^{T M} \text { Tangerine } \\
\text { Eye }\end{array}$ & 81.3 & 14.4 & 4.4 & 4.1 & 2.9 \\
\hline $\begin{array}{c}\text { Funtastic }^{\mathrm{TM}} \text { Golden } \\
\text { Eye }\end{array}$ & 72.5 & 18.0 & 4.4 & 4.3 & 3.8 \\
\hline Funtastic ${ }^{\mathrm{TM}}$ Canary & 77.0 & 14.4 & 3.6 & 3.9 & 3.8 \\
\hline \multicolumn{6}{|c|}{$\begin{array}{l}\text { 'Flower quality was rated on a } 1 \text { to } 5 \text { scale: } 1=\text { very poor; } 3 \text { = fair, some blemishes, but acceptable; and } 5=\text { excellent, bright, uniform, and no } \\
\text { blemishes. }\end{array}$} \\
\hline \multicolumn{6}{|c|}{$\begin{array}{l}\text { "No plant growth regulators were used in these experiments, and plant quality was rated using a } 1 \text { to } 5 \text { scale: } 1=\text { few leaves or long petioles, } \\
\text { container surface visible, very poor and unacceptable as flowering pot plants; } 3=\text { fair and meeting the minimum standard for marketability; } \\
\text { and } 5=\text { excellent, full, attractive, symmetrical plants. }\end{array}$} \\
\hline
\end{tabular}

Table 3. Flowers produced per potted plant of 'Funtastic ${ }^{\mathrm{TM}}$ Tangerine Eye' and 'Funtastic ${ }^{\mathrm{TM}}$ Golden Eye' in comparison to 'Bimini',

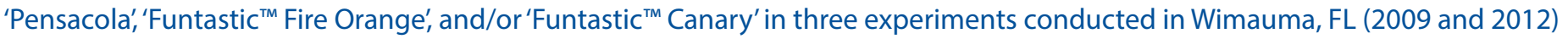

Expt. 1

Expt. 2

Expt. 3

Cultivars

(Flowers counted between Jan. and Mar. 2009)

(Flowers counted between Sept. and Nov. 2009)

(Flowers counted between June

\begin{tabular}{|c|c|c|c|}
\hline Funtastic $^{\mathrm{TM}}$ Tangerine Eye & 4.2 & 6.8 & 8.0 \\
\hline Funtastic $^{\mathrm{TM}}$ Golden Eye & 3.6 & 3.4 & 9.7 \\
\hline Bimini & 3.0 & 4.1 & 2.5 \\
\hline Pensacola & & 10.0 & \\
\hline Funtastic & \\
\hline Funtastic & Fire Orange & & \\
\hline
\end{tabular}

8.0

9.7 
Table 4. Powdery mildew severity on leaves of 'Funtastic ${ }^{\mathrm{TM}}$ Tangerine Eye' and 'Funtastic ${ }^{\mathrm{TM}}$ Golden Eye' in comparison to 'Bimini', 'Pensacola', 'Funtastic ${ }^{\mathrm{TM}}$ Fire Orange', and/or 'Funtastic ${ }^{\mathrm{TM}}$ Canary' in five experiments conducted in Wimauma, FL (2009 and 2012)

\begin{tabular}{|c|c|c|c|c|c|}
\hline \multirow{2}{*}{ Cultivars } & Expt. 4 & Expt. 5 & Expt. 6 & Expt. 7 & Expt. 8 \\
\hline & (Mar. 2009) & (June 2009) & (Oct. 2009) & (Aug. 2012) & (Aug. 2012) \\
\hline $\begin{array}{c}\text { Funtastic }^{T M} \text { Tangerine } \\
\text { Eye }\end{array}$ & 3.6 & 2.7 & 1.7 & 1.5 & 1.0 \\
\hline $\begin{array}{c}\text { Funtastic }^{\mathrm{TM}} \text { Golden } \\
\text { Eye }\end{array}$ & 4.8 & 4.0 & 3.7 & 3.0 & 1.7 \\
\hline Bimini & 7.5 & 6.7 & & & \\
\hline Pensacola & 8.6 & 8.7 & & & \\
\hline $\begin{array}{l}\text { Funtastic }^{\mathrm{TM}} \text { Fire } \\
\text { Orange }\end{array}$ & 6.8 & 4.0 & 3.7 & & \\
\hline Funtastic ${ }^{\mathrm{TM}}$ Canary & 7.4 & 5.7 & 4.2 & 3.3 & 2.8 \\
\hline \multicolumn{6}{|c|}{$\begin{array}{l}\text { NOTE: Powdery mildew severity was rated on a scale of } 1 \text { to } 10 \text { as described by Hausbeck et al. (2002): } 1=\text { no disease, } 2=\text { trace to } 10 \%, 3= \\
10 \% \text { to } 20 \%, 4=20 \% \text { to } 30 \%, 5=30 \% \text { to } 40 \%, 6=40 \% \text { to } 50 \%, 7=50 \% \text { to } 60 \%, 8=60 \% \text { to } 70 \%, 9=70 \% \text { to } 80 \% \text {, and } 10=80 \% \text { to } 100 \% \text { of lea } \\
\text { surface infected with powdery mildew. }\end{array}$} \\
\hline
\end{tabular}

Table 5. Flowers produced per plant of 'Funtastic ${ }^{\top \mathrm{TM}}$ Tangerine Eye' and 'Funtastic ${ }^{\mathrm{TM}}$ Golden Eye' under natural powdery mildew disease pressures in comparison to 'Bimini,' 'Pensacola,',Funtastic ${ }^{\mathrm{TM}}$. Fire Orange', and/or 'Funtastic ${ }^{\mathrm{TM}}$ Canary' in four experiments conducted in Wimauma, FL (2009 and 2012)

\begin{tabular}{|c|c|c|c|c|}
\hline \multirow{2}{*}{$\begin{array}{c}\text { Cultivars } \\
\text { Funtastic }{ }^{\mathrm{TM}} \text { Tangerine } \\
\text { Eye }\end{array}$} & $\begin{array}{c}\text { Expt. 4 } \\
\text { (Jan. to Mar. 2009) }\end{array}$ & $\begin{array}{c}\text { Expt. 5 } \\
\text { (Apr. to June 2009) }\end{array}$ & $\begin{array}{c}\text { Expt. 6 } \\
\text { (Oct. to Nov. 2009) }\end{array}$ & $\begin{array}{c}\text { Expt. 7 } \\
\text { (June to July 2012) }\end{array}$ \\
\hline Funtastic & 4.6 & 8.3 & 2.0 & 6.0 \\
\hline Bimini Golden Eye & 3.2 & 5.0 & 2.0 & 6.0 \\
\hline Pensacola & 2.6 & 1.3 & & \\
\hline Funtastic & & & \\
\hline Funtastic $^{\mathrm{TM}}$ Canary & 3.0 & 1.7 & 5.3 & 6.5 \\
\hline
\end{tabular}

